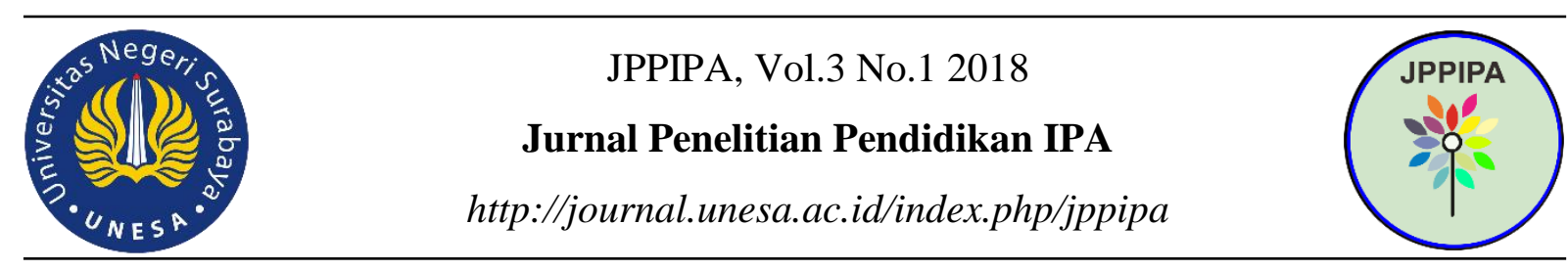

\title{
PENGEMBANGAN MEDIA PEMBELAJARAN OPTIK MENGGUNAKAN SENSOR SERAT OPTIK BUNDLE UNTUK MENENTUKAN KONSENTRASI KOLESTEROL
}

Oleh:

Moh. Budiyanto ${ }^{1}$, Moh. Yasin 2 , Suhariningsih ${ }^{3}$

${ }^{1} J u r u s a n$ IPA, Fakultas MIPA, Universitas Negeri Surabaya, Surabaya 60231, Indonesia.

2,3 Jurusan Fisika, Fakultas Sains and Teknologi, Universitas Airlangga, Surabaya 60115, Indonesia.

\begin{abstract}
Abstrak
Penelitian ini untuk mengembangan media pembelajaran pada perkuliahan optik dengan menggunakan sensor serat optik bundle untuk deteksi konsentrasi kolesterol. Penggunaan media sensor merupakan penerapan praktis konsep rambatan, serapan, dan pemantulan gelombang untuk memecahkan masalah dalam hal ini penentuan konsentrasi kolsterol secara cepat dan akurat. Dengan menentukan parameter-parameter yang dihasilkan oleh sensor serat optik yang akurat dan mekanisme penggunaan media ini mudah diset dengan memandu gelombang melalui serat optik untuk menuju larutan atau bahan yang kemudian dipantulkan kembali melalui serat optik untuk mendeteksi tegangan output. Metode yang digunakan dengan uji media sensor serat optik bundle dengan menentukan parameter dan validasi perangkat media pembelajaran oleh para pakar. Hasil validasi media pembelajaran diperoleh penilaian rata-rata $96,7 \%$ dan analisis pendeteksian menunjukkan bahwa tegangan output maksimum menunjukkan penurunan secara linier terhadap peningkatan konsentrasi larutan kolesterol dengan sensitivitas 0,01 $\mathrm{mV} / \mathrm{ppm}$ dan linieritas $99,6 \%$. Dengan parameter hasil eksperimen dan hasil validasi media pembelajaran rancangan sensor ini diset maka sensor serat optik layak sebagai media pembelajaran untuk mendukung pembelajaran optik.
\end{abstract}

Kata Kunci : media pembelajaran, sensor serat optik bundle, dan larutan kolesterol.

\begin{abstract}
This research is to develop learning media in optical lectures by using bundle optical fiber sensor for detection of cholesterol concentration. The use of sensor media is a practical application of the concept of wave propagation, absorption, and reflection to solve problems in this case the determination of kolsterol concentration quickly and accurately. By determining the parameters produced by an accurate fiber optic sensor and the mechanism of media use is easily set by guiding the wave through the optical fiber to get to the solution or material which is then reflected back through the optical fiber to detect the output voltage. The method used by testing the bundle fiber optic sensor media by determining the parameters and validation of learning media devices by experts. The results of learning media validation obtained an average rating of $96.7 \%$ and detection analysis showed that the maximum output voltage showed a linear decrease in the increase in cholesterol solution concentration with a sensitivity of $0.01 \mathrm{mV} / \mathrm{ppm}$ and linearity of $99.6 \%$. With the parameters of the experimental results and the results of the validation of the learning media the sensor design was set so that the optical fiber sensor was feasible as a learning medium to support optical learning.
\end{abstract}

Keywords: learning media, fiber bundle optic sensor, and cholesterol lsolution.

(C) 2018 Universitas Negeri Surabaya

Alamat Korespondensi:

Jurusan IPA, Fakultas MIPA, Universitas

p-ISSN: 2527-7537

Negeri Surabaya, Surabaya 60231, Indonesia

e-ISSN: 2549-2209

Email: mohammadbudiyanto@unesa.ac.id 


\section{PENDAHULUAN}

Pembelajaran pada umumnya berpegang pada prinsip efisiensi dan efektivitas yakni pemanfaatan waktu yang terbatas secara optimal untuk mencapai tujuan. Karena itu, tiap model, metode, dan media perkuliahan diorientasikan pada tujuan prinsip umum yang digunakan dalam proses belajar mengajar dengan cara belajar konstruktivis. Proses belajar mengajar dituntut adanya interaksi antara pendidik dan peserta didik. Interaksi dalam proses belajar mengajar antara dosen dengan mahasiswa dimana dosen sebagai fasilitator dengan mahasiswa dituntut untuk lebih aktif dalam pembelajaran.

Sistem perkuliahan selama ini dilakukan di dalam kelas melalui presentasi powerpoint yang dilakukan oleh dosen dan mahasiswa dan dievaluasi dengan beban tugas mengerjakan soal latihan konsep yang telah disampaikan. Untuk mengatasi kejenuhan mahasiswa perkuliahan pada materi gaya magnet ini akan menerapkan langsung pada pembuatan alat yang berkaitan dengan materi gaya magnet atau yang di kenal Gaya Lorentz melaui kegiatan penelitian tindakan kelas. Untuk memudahkan pemahaman konsep gaya Lorentz dan aplikasinya dalam kehidupan sehari-hari, mahasiswa disuruh membuat alat rangkaian motor listrik dengan bahan bekas yang mudah didapat dengan kreasi mahasiswa sendiri. (Jatmiko B. et al., 2015).

media pembelajaran merupakan salah satu sumber belajar yang dapat memperkaya wawasan anak didik. Peranan media tidak akan terlihat bila penggunaanya tidak sejalan dengan isi dan tujuan pembelajaran yang telah dirumuskan. Karena itu, tujuan pembelajaran harus dijadikan sebagai acuan dalam menggunakan media.

Media pembelajaran adalah segala sesuatu yang dapat menyalurkan pesan, dapat merangsang fikiran, perasaan, dan kemauan peserta didik sehingga dapat mendorong terciptanya proses belajar pada diri peserta didik.

Berikut ini adalah manfaat dan fungsi media di dalam pembelajaran.

1. Menarik perhatian, dengan demikian dapat meningkatkan motivasi, karena salah satu komponen motivasi adalah perhatian (attention). Unsur-unsur media yang berwarna, bergerak sangat membantu menarik perhatian.

2. Meningkatkan kualitas belajar. Dengan penggunaan media yang bervariasi member peluang penggunaan indera yang bermacammacam dalam menerima pesan, dengan demikian kualitas belajar menjadi lebih baik karena melibatkan banyak indera dan selanjutnya akan meningkatkan retensi.

3. Mengurangi verbakistis, sehingga penyajian menjadi lebih jelas, mengurangi kebosanan.

4. Mengatasi keterbatasan ruang, waktu dan kemampuan indera. Objek yang terlalu besar seperti bumi dapat diganti dengan model (globe), objek yang terlalu kecil dapat dibesarkan misalnya gambar sel, begitu pula film dan rekaman video, peserta didik dapat mengamati proses yang hampir mirip aslinya meskipun kejadiannya trelah berlangsung jauh sebelumnya dan di tempat yang jauh pula.

5. Mengaktifkan peserta didik dan memudahkan untuk menciptakan persepsi yang sama pada siswa.

Media pembelajaran dalam pembelajaran sains merupakan sarana yang berfungsi menyampaikan informasi belajar dapat memberikan kontribusi positif dalam proses pembelajaran yang interaktif, efektif dan menumbuhkan rasa ingin tahu siswa terhadap konsep-konsep sains yang ditunjukkan oleh media tersebut.

Serat optik adalah saluran transmisi sejenis kabel yang terbuat dari kaca atau plastik yang sangat halus dan dapat digunakan untuk mentransmisikan sinyal cahaya dari suatu tempat ke tempat lain. Sumber cahaya yang digunakan biasanya adalah laser. Kabel ini berdiameter lebih kurang 120 mikrometer. Cahaya yang ada di dalam serat optik tidak keluar karena indeks bias dari kaca lebih besar daripada indeks bias dari udara, karena laser mempunyai spektrum yang sangat sempit.Pada prinsipnya serat optik memantulkan dan membiaskan sejumlah cahaya yang merambat didalamnya. Efisiensi dari serat optik ditentukan oleh kemurnian dari bahan penyusun gelas/kaca. Semakin murni bahan gelas, semakin sedikit cahaya yang diserap oleh serat optik.

Gambar 1 menunjukkan skema dasar sensor pergeseran serat optik, sumber cahaya (S) masuk kedalam serat pemancar (TF) dan mengenai sasaran, kemudian cahaya dipantulkan oleh permukaan sasaran dan ditransmisikan kembali melalui serat penerima (RF) yang kemudian ke fotodetekor (D). (M. Budiyanto, 2018)

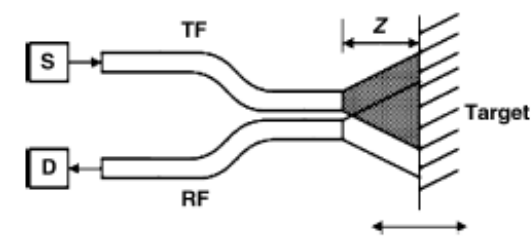

Gambar.1. Susunan dasar serat optik Untuk analisi teori dengan menggunakan serat optik bundel dengan susunan berbentuk pasangan dapat diasumsikan sebagai berikut (M. Budiyanto, 2018),

- Susunan ujung bundel di depan cermin antara serat pemancar dan serat penerima dianggap sejajar dan tidak ada ruang atau jarak pisah antara keduanya. Luas penampang kedua serat dianggap berbentuk lingkaran sempurna dengan luas $S_{a}$ dan jari-jari $\omega_{a \text {. }}$ 
- Cahaya yang meninggalkan serat bundel pemancar diwakili oleh kerucut simetris sempurna dengan sudut sebaran (divergence) $\theta_{a}$, pusatnya di titik $O$ dengan jarak $\mathrm{z}_{\mathrm{a}}$ di dalam serat bundel.

Adapun sampel larutan untuk uji eksperimen pada media pembelajaran sensor serat optik adalah kolesterol. Kolesterol sebenarnya merupakan salah satu komponen lemak. Lemak merupakan salah satu zat gizi yang sangat diperlukan oleh tubuh disamping zat gizi lain seperti karbohidrat, protein, vitamin dan mineral. Senyawa lemak merupakan salah satu sumber energi yang memberikan kalori paling tinggi. Disamping sebagai salah satu sumber energi, sebenarnya lemak atau khususnya kolesterol memang merupakan zat yang sangat dibutuhkan oleh tubuh untuk membentuk dinding sel-sel dalam tubuh. Kolesterol juga merupakan bahan dasar pembentukan hormon-hormon steroid. Kolesterol yang dibutuhkan tersebut, secara normal diproduksi sendiri oleh tubuh dalam jumlah yang tepat. Kolesterol dalam tubuh yang berlebihan akan tertimbun di dalam dinding pembuluh darah dan menimbulkan suatu kondisi yang disebut aterosklerosis yaitu penyempitan atau pengerasan pembuluh darah. Kondisi ini merupakan cikal bakal terjadinya penyakit jantung dan stroke.

Dari hati, kolesterol diangkut oleh lipoprotein yang bernama LDL (Low Density Lipoprotein) untuk dibawa ke sel-sel tubuh yang memerlukan, termasuk ke sel otot jantung, otak dan lain-lain agar dapat berfungsi sebagaimana mestinya. Kelebihan kolesterol akan diangkut kembali oleh lipoprotein yang disebut HDL (High Density Lipoprotein) untuk dibawa kembali ke hati yang selanjutnya akan diuraikan lalu dibuang ke dalam kandung empedu sebagai asam (cairan) empedu. LDL mengandung lebih banyak lemak daripada HDL sehingga ia akan mengambang di dalam darah. HDL ini mempunyai kandungan lemak lebih sedikit dan mempunyai kepadatan tinggi sehingga lebih berat.

Kolesterol merupakan produk khas hasil metabolisme hewan. Dengan demikian semua makanan yang berasal dari hewan, seperti kuning telur, daging, hati, dan otak sudah jelas mengandung kolesterol. Biosintesis kolesterol terbanyak berlangsung dalam jaringan hati, kulit, kelenjar lemak ginjal, kelenjar kelamin.

Kolesterol dapat larut dalam pelarut organik, misalnya eter, kloroform, benzene, karbon disulfida, aseton, dan alkohol panas, tetapi tidak larut dalam air, asam atau basa. Pada konsentrasi tinggi, kolesterol mengkristal dalam bentuk kristal tak berwarna, tidak berasa, tidak berbau, dan memiliki titik lebur $150^{\circ} \mathrm{C}-151^{\circ} \mathrm{C}$. Di udara terbuka atau terkena sinar matahari langsung, kolesterol akan teroksidasi secara lambat menjadi senyawa yang memiliki titik lebur lebih rendah dan akan berubah sifat reaksinya .

Dari uraian tersebut peneliti ingin memberikan salah satu solusi pengembangan media pembelajaran pada perkuliahan optik dengan menggunakan sensor serat optik untuk deteksi konsentrasi kolesterol. Penggunaan media sensor merupakan penerapan praktis konsep rambatan, serapan, dan pemantulan gelombang untuk memecahkan masalah dalam hal ini penentuan konsentrasi kolsterol secara cepat dan akurat. (Budiyanto et al., 2018). Dengan menentukan parameter-parameter yang dihasilkan oleh sensor serat optik yang akurat dan mekanisme penggunaan media ini mudah diset dengan memandu gelombang melalui serat optik untuk menuju larutan atau bahan yang kemudian dipantulkan kembali melalui serat optik untuk mendeteksi tegangan output, maka dapat dikatakan penggunaan sensor ini mudah dan sederhana serta berpotensi sebagai media pembelajaran gelombang dan optik.

\section{METODE}

Penelitian ini merupakan penelitian deskriptif yang mendeskripsikan hasil penelitian secara kuantitatif disertai dengan penjelasan sesuai dengan teori yang diacu dalam penelitian. Adapun prosedur penelitian ini diawali dengan validasi media pembelajaran sensor serat optik pada tiga validator dan didukung oleh data uji hasil eksperimen dari media pembelajaran sensor serat optik.

Metode yang digunakan dengan uji media sensor serat optik bundle dengan menentukan parameter dan validasi perangkat media pembelajaran oleh para pakar. Metode penelitian menentukan konsentrasi kolesterol ditentukan berdasarkan karakter sinar laser terhadap bahan melalui sensor serat optik dengan menggunakan modulasi intensitas sinar Laser. Berkas cahaya yang masuk ke serat optik penerima dan diproses oleh detektor optik menjadi sinyal listrik yang akan ditampilkan di komputer. Hasil eksperimen akan diperoleh hubungan linieritas antara tegangan puncak luaran sensor sebagai fungsi variasi konsentrasi kolesterol dan akan diukur paramater dan kinerja sensor meliputi sensitivitas, jangkauan linier, dan linieritas.

Perangkat penelitian terdiri dari laser $\mathrm{He}-\mathrm{Ne}$ (Thorlabs, $632.5 \mathrm{~nm}, 5 \mathrm{~mW}$ ), Serat optik bundle, detektor optik 818-SL (Newport), chopper dan chopper controler (SR540, Stanford Research System, Inc.), Lock-in amplifier (SR510, Stanford Research System, Inc.), cermin panjang gelombang cahaya tampak (5101-Vis, New Focus), 
mikrometer posisi (Newport), PC, serta perangkat pendukung lainnya.

Langkah awal adalah melakukan karakterisasi sensor pergeseran untuk mengetahui pergeseran kanal sensing serat bundle terhadap cermin datar. Selanjutnya adalah melakukan deteksi konsentrasi kolesterol dengan membuat set-up seperti gambar berikut :

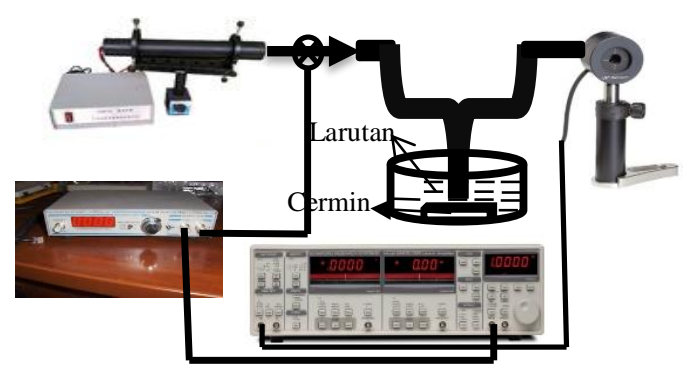

Gambar 2. Sensor serat optik menggunakan serat bundle

Pendeteksian dimulai saat serat bundle yang ditempatkan berimpit dengan cermin yakni pada pergeseran $\mathrm{z}=0$. serat bundle ditempatkan pada mikrometer posisi digeser tiap $50 \mu \mathrm{m}$. Pada tiap posisi pergeseran tegangan keluaran detektor diukur sehingga diperoleh data berupa tegangan luaran detektor sebagai fungsi pergeseran serat bundle. Pendeteksian dilakukan terhadap beberapa variasi konsentrasi antara lain 0 ppm, 50 ppm, 100 ppm, 150 ppm, 200 ppm, 250 ppm, 300 ppm.

\section{HASIL DAN PEMBAHASAN}

Hasil eksperimen menggunakan cermin datar ital untuk mengukur nilai tegangan luaran maksimum dari variasi konsentrasi kolesterol seperti pada Gambar 3. Gambar tersebut menunjukkan grafik tegangan keluaran detektor sebagai fungsi pergeseran fiber bundle menggunakan voltmeter digital untuk masingmasing konsentrasi mulai 0 ppm sampai 300 ppm.

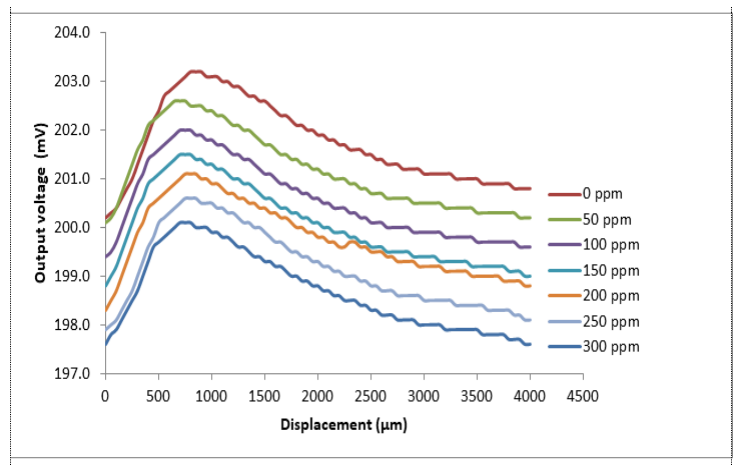

Gambar 3. Grafik tegangan keluaran detektor sebagai fungsi pergeseran serat bundle
Berdasarkan hasil eksperimen penentuan konsentrasi kolesterol menggunakan SSO menunjukkan bahwa profil daya luaran serat optik akan bertambah dengan bertambah jarak pergeseran objek dari bundel serat optik, setelah mencapai puncak daya luaran akan berkurang secara eksponensial dengan bertambahnya jarak pada masing-masing variasi konsentrasi kolesterol seperti tampak pada gambar 3. (Rahman A. et al., 2012).

Gambar 3. menunjukkan bahwa konsentrasi 0 ppm luaran tegangannya dimulai $200,1 \mathrm{mV}$ pada jarak minimum. Bertambahnya jarak terhadap sampel larutan mempengaruhi naiknya nilai tegangan luaran sampai mencapai tegangan output maksimum sebesar 203,2 mV pada jarak $1850 \mu \mathrm{m}$. Setelah mencapai puncak tegangan luaran maksimum dengan bertambahnya jarak terhadap sampel larutan, tegangan luaran mengalami penurunan nilai tegangan secara eksponensial. Pada sampel kedua dengan konsentrasi $50 \mathrm{ppm}$ tegangan luaran minimumnya dimulai $200,0 \mathrm{mV}$ dan semakin bertambah naik tegangan dengan bertambahnya jarak terhadap sampel larutan sampai mencapai nilai tegangan output maksimum 202,6 mV pada jarak $800 \mu \mathrm{m}$. Kemudian dengan bertambahnya jarak terhadap sampel, tegangan luaran mengalami penurunan secara eksponensial. Pada sampel ketiga konsentrasi 100 ppm luaran tegangannya dimulai 199,8 $\mathrm{mV}$ pada jarak minimum. Bertambahnya jarak terhadap sampel larutan mempengaruhi naiknya nilai tegangan luaran sampai mencapai tegangan output maksimum sebesar $202,0 \mathrm{mV}$ pada jarak $650 \mu \mathrm{m}$. Setelah mencapai puncak tegangan luaran maksimum dengan bertambahnya jarak terhadap sampel larutan, tegangan luaran mengalami penurunan nilai tegangan secara eksponensial. Sampel keempat dengan konsentrasi $150 \mathrm{ppm}$ tegangan luaran minimumnya dimulai $198,8 \mathrm{mV}$ dan semakin bertambah naik tegangan dengan bertambahnya jarak terhadap sampel larutan sampai mencapai nilai tegangan output maksimum 201,5 mV pada jarak $700 \mu \mathrm{m}$. Kemudian dengan bertambahnya jarak terhadap sampel, tegangan luaran mengalami penurunan secara eksponensial.

Konsentrasi larutan kolesterol 200 ppm luaran tegangannya dimulai 198,2 $\mathrm{mV}$ pada jarak minimum. Bertambahnya jarak terhadap sampel larutan mempengaruhi naiknya nilai tegangan luaran sampai mencapai tegangan output maksimum sebesar 201,1 mV pada jarak $700 \mu \mathrm{m}$. Setelah mencapai puncak tegangan luaran maksimum dengan bertambahnya jarak terhadap sampel larutan, tegangan luaran mengalami penurunan nilai tegangan secara eksponensial.

Sampel keenam dengan konsentrasi $250 \mathrm{ppm}$ tegangan luaran minimumnya dimulai $198,0 \mathrm{mV}$ 
dan semakin bertambah naik tegangan dengan bertambahnya jarak terhadap sampel larutan sampai mencapai nilai tegangan output maksimum 200,6 mV pada jarak $750 \mu \mathrm{m}$. Kemudian dengan bertambahnya jarak terhadap sampel, tegangan luaran mengalami penurunan secara eksponensial. Sampel ketujuh konsentrasi 300 ppm luaran tegangannya dimulai $197,8 \mathrm{mV}$ pada jarak minimum. Bertambahnya jarak terhadap sampel larutan mempengaruhi naiknya nilai tegangan luaran sampai mencapai tegangan output maksimum sebesar $200,1 \mathrm{mV}$ pada jarak $750 \mu \mathrm{m}$. Setelah mencapai puncak tegangan luaran maksimum dengan bertambahnya jarak terhadap sampel larutan, tegangan luaran mengalami penurunan nilai tegangan secara eksponensial.

Profil daya luaran hasil eksperimen dari sampel tujuh variasi konsentrasi kolesterol menggunakan berkas kuasi Gaussian menunjukkan bahwa daya luaran serat optik akan bertambah dengan bertambah jarak pergeseran obyek dari bundel serat optik (Faria, 2000). Hal ini dapat diindikasikan adanya kenaikan tegangan sampai mencapai tegangan maksimum. Setelah mencapai puncak daya luaran akan berkurang secara eksponensial dengan bertambahnya jarak. Tegangan maksimum dari masing-masing sampel mengalami penurunan dengan bertambahnya konsentrasi kolesterol yang disebabkan oleh serapan energi. Dengan bertambahnya konsentrasi larutan dari sampel yang digunakan, semakin besar pula serapan energinya yang menyebabkan tegangan maksimum semakin menurun.

Berdasarkan hasil analisis tegangan puncak terhadap variasi konsentrasi kolesterol menggunakan sensor serat optik bundle menunjukkan sensitivitas $0,01 \mathrm{mV} / \mathrm{ppm}$ dan linieritas 99,62\%. Hasil analisis data menentukan konsentrasi kolesterol dengan menggunakan sensor ini sesuai dengan analisis yang diperoleh teoritis (M.Yasin et al., 2013).

Berdasarkan hasil validasi oleh para validator secara umum perangkat pembelajaran yang dikembangkan telah layak digunakan dengan beberapa revisi. Hasil penilaian validasi media pembelajaran diperoleh penilaian rata-rata $96,7 \%$ seperti pada tabel 1 .

Tabel 1. Hasil penilaian validasi media pembelajaran

\begin{tabular}{|c|c|c|}
\hline No. & Aspek yang dinilai & $\begin{array}{r}\text { Prosentase } \\
\text { penilaian }(\%)\end{array}$ \\
\hline 1 & Pemilihan media Sensor serat Optik sesuai dengan KD, Indikator & 93,3 \\
\hline 2 & Media Sensor serat Optik sesuai dengan tujuan pembelajaran & 100 \\
\hline 3 & $\begin{array}{l}\text { Media Sensor serat Optik sesuai dengan materi sifat-sifat cahaya } \\
\text { dan alat optik }\end{array}$ & 93.3 \\
\hline 4 & $\begin{array}{l}\text { Media Sensor serat Optik sesuai dengan praktikum yang terdapat } \\
\text { pada lembar kerja mahasiswa }\end{array}$ & 93,3 \\
\hline 6 & $\begin{array}{l}\text { Media Sensor serat Optik dapat melatihkan keterampilan proses } \\
\text { mahasiswa }\end{array}$ & 100 \\
\hline 7 & KIT mudah digunakan dan terbuat dari bahan yang Sederhana & 100 \\
\hline
\end{tabular}

\section{PENUTUP}

Hasil penilaian validasi media pembelajaran diperoleh penilaian rata-rata $96,7 \%$ dan analisis pendeteksian menunjukkan bahwa tegangan output maksimum menunjukkan penurunan secara linier terhadap peningkatan konsentrasi larutan kolesterol dengan sensitivitas $0,01 \mathrm{mV} / \mathrm{ppm}$ dan linieritas 99,6\%. Dengan parameter hasil eksperimen dan hasil validasi media pembelajaran rancangan sensor ini diset maka sensor serat optik dapat berpotensi sebagai media pembelajaran untuk mendukung pembelajaran optik.

\section{DAFTAR PUSTAKA}

M. Budiyanto. 2018. Sensor serat optik berkas kuasi Gaussian untuk menentukan konsentrasi kolesterol. Disertasi,Universitas Airlangga

Budiyanto.M., Suhariningsih dan Yasin M. 2018. Potency of sensor displacement detection of cholesterol concentration using flat mirror as media for learning waves and optics. J.Phys.Conf. Series.1006.

Faria J.B, 2000, Modeling The $\gamma$-Branched Optical Fiber Bundle Displacement Sensor Using a Quasi-Gaussian Beam Approach, Microwave and Optical Technologi Letters, Vol. 25 No.2. pp. 138-141.

Jatmiko B, Wahono W., Martini, Budiyanto M. 2015. Buku Prototipe Kurikulum Pendidikan Sains Berorientasi KKNI. Jaudar Press.

Rahman H. A., S. W. Harun, M. Yasin, H. Ahmad. 2012. Fiber Optic Salinity Sensor Using Fiber Optic Displacement Measurement 
Moh. Budiyanto, Moh. Yasin, Suhariningsih, JPPIPA (Jurnal Penelitian Pendidikan IPA), Vol. 3, No. 1, 39-44

with Flat and Concave Mirror. IEEE Journal of Selected Topics in Quantum Electronics, Vol. 18, No. 5, pp. 1529 - 1533.

Yasin M., H. Ahmad, K. Thambiratnam, A. A. Jasim, S. W. Phang, S. W. Harun. 2013. Design of Multimode Tapered Fibre Sensor for Glucose Detection, Optoelectronics and Advanced Materials Vol. 7, No. 5 - 6. p. 371 - 376. 